\title{
RABBI JOSEPH B. SOLOVEITCHIK'S ENDORSEMENT AND CRITIQUE OF VOLKISH THOUGHT
}

\section{By: Daniel Herskowitz}

\begin{abstract}
:
In this article I trace and examine volkish elements in Rabbi Joseph B. Soloveitchik's thought. My claim is that Soloveitchik is influenced by different notions of volkish ideology which are applied to the Jewish volk. These notions enrich his thought and provide a language to articulate different ideas concerning the Jewish peoplehood in modernity. Yet Soloveitchik was also aware and critical of the ethical problems volkish ideology brings rise to - a critique that is exemplified in his reaction to the philosophy of Martin Heidegger. Soloveitchik thus adopts volkish notions and employs them in a Jewish context yet is simultaneously highly critical of this vain of thought and its ethical ramifications. This apparent disparity is explained through an understanding of the connection between reason and ethics in Soloveitchik's thought. Through this we find that the volkish endorsement into a Jewish context can be religiously productive yet also morally risky.
\end{abstract}

A. 
This study will deal with the existence of volkish strains in Soloveitchik's thought. These appear throughout his writings and consist of an important aspect of his thought as a whole. This, I hold, will be proven to be another example of a tendency amongst twentieth century Jewish thinkers to endorse different elements of European volk ideology. ${ }^{1}$ Ultimately, we will witness a complex dynamic at play in Soloveitchik's usage of volkish elements: themes from the volkish world view are expressed, yet in a revised form in order to appropriately suit the Jewish case. Besides assuming Jewish relevance, the revision makes sure to jettison some of the morally difficult aspects that arise from volkish thought. At last, the adoption of volkish elements by Soloveitchik finds its justification by the insinuated claim that these elements root, as a matter of fact, from a 'Jewish' origin.

The order of discussion will be as follows: First I succinctly describe a cluster of ideas that pertain to what is often referred to as volkish ideology. Second, I gather a few examples proving that Soloveitchik puts this ideology's ideas and terms into play. Third, I argue that even though he adopts volkish ideas and terminology, the ethical pits this path of thought could occupy are nonetheless recognized and offered some form of resolution by him. Fourth, I show that Soloveitchik's critical assessments towards Martin Heidegger and his thought could be perceived as a case study of the former's critique of volkish thought. Finally, I offer an explanation as to how Soloveitchik could both employ volkish notions and simultaneously be highly critical of the logic that stands in their foundation.

Scholars have rightly situated Soloveitchik's thought within two major schools of thought: neo-Kantianism (the Marburg school) and existentialism. Lately, Romanticism, to which existentialism is closely related, has been suggested as an additional vain of thought that could be identified in Soloveitchik's homiletic and written work. ${ }^{2}$ One of the main goals of this study is to show the legitimacy of adding volkish ideology to the list of western philosophical influences on his thought. As will be shown, this ideology has contributed to Soloveitchik's conception of Am Israel (the Jewish People).

B. 
What is a volk? The meaning of 'volk' is not exhausted by the common - yet overly narrow - translation to 'People' or to the more updated 'Peoplehood'. ${ }^{3}$ Since the term is not easily clarified or defined, an analogy, widely used by volkish thinkers themselves, may prove to be efficient for its explanation. A volk is most effectively described by analog to a live organism. Indeed, an essential conviction of European nationalism according to Isaiah Berlin is "that the pattern of life of a society is similar to that of a biological organism". 4 Nearly every natural organism is composed from a multiplicity of organs, segments and parts, yet it functions as a united and collaborative entity. The specific organ operates naturally in a way that maximizes the prosperity, endurance and purpose of the organ as a whole. This analogy from the natural world is often provided to explain the relations between the different members of the volk and the volk as a whole. As Herder has emphasized repeatedly, the members of the well-functioning volk operate in a united and harmonious manner as if they were a biological organ. Although distinct and sometimes in need of different or even contradictory things, the prosperity, endurance and purpose of the volk and nothing else directs their decisions. They are together an all-encompassing one and united entity (consider Adolf Grabowsky (1880-1969): “Das Gemeinsame von Staat und Organismus ist das Leben aus eigenem Recht”). The naturalistic metaphor is so central to volkish understanding that, indeed, volkish thinkers took it literally all too often, hence the frequent acceptance of racist convictions. To be sure, not everyone agreed with naturalistic racist ideas, and not all volkish thinkers were necessarily xenophobic. Martin Buber, for one, was a devote advocate of volkish ideology, though the volk he spoke of - the Jewish volk - was, in his opinion, destined to eventually transcend and dilate to all mankind.

The interconnectedness of the volk's members is indeed fundamental, however the essence of the volk is not manifested completely by its constituent members and the relations between them alone; rather the volk denotes to a whole greater than the sum of its parts, exceeding each and every member and the sum of the collective. This feature becomes possible only if the volk is perceived as more than just a social construction; only if it is also, or rather, mainly, an abstract entity in which the actual members are its partial representatives. As Leo Frobenius, the German Ethnologist put it, the volk is to be seen as "a living 
creature". As such, characteristics, features, and even something that can be referred to as a personality are attributed to the volk.

This leads to an additional important aspect of volkish ideology: The personality of the volk corresponds to what is considered to be the volk's mission. Huizinga correctly describes as bearing religious temperament: "They are aware of a mission, of having a calling, of being chosen for something. A divinity to charge them with a mission is hardly necessary any longer: the nation is enough to itself'. 5 The volk bears a spiritual and even metaphysical vocation bound to be fulfilled in history. It is regularly referred to as the destiny [Schicksal] or fate [Geshick] of the volk. ${ }^{6}$ In the German context, this mission is considered a part of the volk's Innerlichkeit, the sublime imminent feature of its unique nature awaiting actualization. What often emerges from this position is that actions that express this distinct and 'personal' Innerlichkeit or contribute to the realization of the destiny are imperative, or, stated more poignantly, are morally worthy. Volkish ideology thus often obtains a profound anti-universalistic attitude, applying specific standards to itself that do not apply to others.

Returning to the social aspects mentioned above, an additional and often interchangeable term to volk is Gemeinschaft. Coined by the German sociologist Ferdinand Tönnies in his 'Gemeinschaft und Gesellschaft' (1887), this term acquired a political meaning by a fundamental negation and distinction from its opposite term, Gesellschaft. While the latter refers to a mechanical, selfish and utilitarian (modern) society in which its members relate to each other superficially as means to an external end, a Gemeinschaft refers to a community in which its members have established an organic, deep and unselfish connection to each other. Like an organism, members of this social body are naturally related, interaction with sincere reciprocity and care. Occasionally the terms volk and Gemeinschaft are linked together to create the Volksgemeinschaft, roughly translated to 'the people's community'. In contrast to members of a Gesellschaft who lack any profound identity, members of a Gemeinschaft enjoy a stable and rooted identity by virtue of a wellestablished tradition and mores according to which they conduct their lives. Here we are introduced to an important notion - tradition, or its closely related term - 'heritage' [Erbe]. These concepts enjoy high status 
in volkish thought for they are what expresses and conveys the inner truth imbibed in the spirit of the volk and are able to divulge the spiritual linkage between past, present and future generations. As stated above, in essence, the volk encompasses far more than only its present members, as its essence is portrayed in the historical mission it harbors. And both its trans-generational nature and its essence are transmitted through heritage. True, the tradition indicated here often turns out to be a highly nostalgic and romanticized version of the past, yet it nonetheless explains the customary interest in occultism and folklore volkish movements often entertain and promote.

Certain normative conclusions follow from the conviction that the volk is a metaphysical entity larger than the sum of its constituents. One is that the volk holds precedence over each and every one of its constituent members. A ramification of this is that the individual is expected to dedicate all her efforts - and even sacrifice her life if needed - for the wellbeing of her volk. As Johann Gottlieb Fichte declared in his Address to the German Nation (1807): "Hence, the noble-minded man will be active and effective, and will sacrifice himself for his people [...] in order to save his nation he must be ready even to die that it may live". ${ }^{7}$ Indeed, struggle and sacrifice are incumbent on those who have been destined to a unique vocation. He who is true to his volk - and to himself - must participate in the ongoing struggle for the realization of its destiny. Conceptually, the struggle is against the reign of the Gesellschaft, the fallen society whose essential functions stand as an obstacle to the possibility of a fateful realization. Other volks and their own struggle for realization could be hindrances to this fulfillment as well. It is thus obligatory to ensure the flourishing of the Geminschaft in this troublesome and challenging reality lest its fallen competitors shall triumph.

These ideas, coined in sum as 'the ideas of 1914' by Ernst Troeltsch, were part of an ongoing climate of opinions that gained popularity with Germany's unification in 1870, a popularity that continued to grow and culminated around the time of World War I. Although not a homogeneous cohort, nationalistic thinkers throughout the war asseverated these opinions in attempt to demonstrate what in their mind was the objective justice implicit in German victory, and, after the German defeat, the 'stab-in-the-back' explanation that fueled anti-democratic and nationalistic groups throughout the Weimar Republic. 'The 
ideas of 1914' forcefully reemerged in Germany towards the end of the twenties and the beginning of thirties as an apparent revisited state of crisis loomed throughout the country, a crisis that found its poignant expression in the escalating support of the National Socialist Party. Nationalistic views concerning the vocation and metaphysical quality of the German volk were once again voiced loudly and confidently in the public sphere and were adhered by the many of the intelligentsia as well. ${ }^{8}$

This quick review of volkish ideas will serve us in the following discussion about Soloveitchik's ambiguous relation to this school of thought.

C.

In his thought, Rabbi Joseph B. Soloveitchik deals with questions concerning man as such: the individual in general and specifically the modern religious person. Many of the topics he tackles, such as repentance, prayer and mourning, are explored through the prism of the individual. However, while his concern is largely directed towards the individual's existential and religious predicament, it is rare that the individual will be discussed as a detached entity, isolated from her community or nation. A person's social context has ample existential and religious significance; so much so that it is, according to Soloveitchik, prerequisite for existential redemption. In fact, dissociating the individual's path to redemption from the collective's redemptive process is virtually impossible, as both are conceptually intertwined. As Rivka Horwitz writes "[Rav Soloveitchik] stresses that the individual's need to be supported by the community, and the community's need as a collective to get closer to God: these two dynamics, the esoteric and exoteric, are necessary for the religious experience. Rav Soloveitchk revealed in this respect an important religious phenomenon unattended by many $[\ldots]$ the individual is constructed by the community and simultaneously constructs it". ${ }^{9}$ Similarly, Ish-Shalom maintains that "when the subject of the Rav's discussion is individual redemption [in the essay 'Redemption, Prayer, Talmud Torah'], its model is Exodus, that is, national redemption". ${ }^{10}$ As Soloveitchik reiterates in various passages in his writings, a person's existential fulfillment is not frustrated by communal interaction: the latter, in fact, enables it. 
While stressing the essentiality of a community to personal existence is still a far cry from adhering to volkish ideology, we shall now see that volkish ideas are explicitly and implicitly proclaimed by Soloveitchik. It may go without saying that for him the connoted volk is the Jewish volk, also referred to by him as Am Israel or Knesset Israel.

Consider the characterization of Am Israel presented by Soloveitchik in one of his articles:

"The community in Judaism is not a functional-utilitarian but an ontological one. The community is not just an assembly of people who work together for their mutual benefit, but a metaphysical entity, an individuality: I might say, a living whole, in particular, Judaism has stressed the wholeness and the entity of Knesset Israel, of the Jewish community. The latter is not a conglomerate, it is an autonomous entity, endowed with a life of its own". ${ }^{11}$

The features in which the Jewish community is outlined here unequivocally mirror voklish terminology. Am Israel is not a collection of disconnected members or even a collective of members who entertain a substantive connection one to another; no - the Jews form together an entity that transcends those who constitute it and amount to a 'metaphysical entity', and as such is cohesive, independent and whole. Knesset Israel is larger than the mere sum of bney Israel in a particular generation, or in all generations for that matter. It is rightly described not simply as a People but as an entity possessing a life of its own, 'an individuality', 'a living whole'.

Elsewhere, Soloveitchik specifies the correct relationship between the individual Jew and Knesset Israel. Here too the mark of volkish thought is apparent:

"The Jew who believes in Knesset Israel is the Jew who lives as a part of it wherever it is and willing to give his live for it, feels its pain, rejoices with it, fights in its wars, groans at its defeats and celebrates its victories. The Jew who believes in Knesset Israel is a Jew who binds himself with unseverable bonds not only to the People of Israel of his own generation but to the community of Israel throughout the ages." 12 
Keeping in mind the volkish background could sheds illuminating light on this statement. Assuming Knesset Israel is the Jewish volk, Soloveitchik appropriately expects the individual to identify with it unconditionally. In line with the volkish logic, one may even have to concede to sacrifice oneself for it when needed. Moreover, Knesset Israel here is personified, feeling pain and experiencing rejoice. It is merely a nation, but a living entity with feelings and reactions. The notion of Mavet al Kidush Hashem, sanctifying God's name through self-sacrifice, is tragically known and has been executed many a time throughout Jewish history. What Soloveitchik expresses here, however, is rather different. The sacrifice imperative here is in the name of the "community of Israel throughout the ages", not God's name. This strongly implies a granted ontological status for Knesset Israel. Furthermore, the Jew is not only to identify with his nation and strive for its success, he ought to believe in the Jewish people - a rather vague and unusual demand.

That volkish ideas and notions are found in Soloveitchik's writings could be further demonstrated by exploring his more celebrated writings. In 'the Lonely Man of Faith' (henceforth LMF) Soloveitchik, following his midrashic interpretation of the two stories of creation in Genesis, famously depicts two types of man - majestic man and man of faith (or Adam the first and Adam the second, respectively). ${ }^{13}$ Although the two types of man differ essentially in characteristics, they are both equally unable to exist solitarily and are inclined to establish a typical community within which they can address their existential challenges. As Fishman points out, the communities established by the two Adams, the natural community and the community of covenant, respectively, resemble the sociological distinction between Gemeinschaft and Gesellschaft. ${ }^{14}$ Members of the utilitarian natural community of Adam the first are connected by personal interest, while the members of the covenantal community of Adam the second are existentially and ontologically linked:

"The covenantal faith community, in contradistinction to the natural work community, interprets the divine pronouncement "It is not good for man to be alone", not in utilitarian but in ontological terms [...] The companionship which Adam the second is seeking is not to be found in the 
depersonalized regimentation of the army, in the automatic coordination of the assembly line, or in the activity of the institutionalized, soulless political community. His quest is for a new kind of fellowship, which one finds in the existential community. There, not only hands are joined, but experiences as well; there, one hears not only the rhythmic sound of the production line, but also the rhythmic beat of hearts starved for existential companionship and all-embracing sympathy and experiencing the grandeur of the faith community; there, one lonely soul finds another soul tormented by loneliness and solitude yet unqualifiedly committed". ${ }^{15}$

Yet it is important to point out that while Tönnies' sociological distinction clearly stands in the basis of Soloveitchik's description, Soloveitchik abstains from pushing a similar evaluative point as the volkish tradition does. Neither community, Soloveitchik posits, exclusively fulfills the will of God. Rather, the dialectical movement of participating in both communities attains religious and existential fulfillment. We can detect here a deviation from the standard volkish view that is unwilling to grant Gesellschaft positive value as a salient aspect of authentic life. We will return to this point later.

A further example of the application of the distinction between Gemeinschaft and Gesellschaft in Soloveitchik's work, one that goes unmentioned by Fishman, exists in the earlier 'Fate and Destiny' ['Kol Dodi Dofek', henceforth FD]. In this work Soloveitchik sketches out two distinguished modes of sociability: Congregation (Eda) and Camp (Mahane). He writes: "The camp is created as a result of the desire for selfdefense and is nurtured by the sense of fear; [...] A congregation is a group of individuals possessing a common past, a common future, common goals and desires, a common aspiration for a world which is wholly good and beautiful, and a common unique, and unified destiny."16 The resemblance to the volkish distinction between Gemeinschaft and Gesellschaft is manifest: 'Camp' is defined as the latter and 'Congregation' reflects the former. This social distinction could typically correlate to the conceptual pair 'destiny' and 'fate' we discussed above: a community that shares common aspirations and conduct is a community of destiny, while a communal identity that is furnished by various reactions to external threats and deals with survival and functionality belongs to a community of fate. In this case too Soloveitchik 
concludes that not one sole mode of sociality is redemptive in isolation but rather the dialectic that is created through living in both are necessary for the establishment of a stable, normative and rooted national identity.

Another explicit use of volkish terminology is displayed in FD. FD deals with the question of suffering from a religious and existential perspective. According to Soloveitchik, in the encounter with suffering a person has two options of response: fate or destiny. Fate is described as "a pure factual existence [...] devoid of meaning, direction, purpose, but subject to the forces of the environment unto which the individual has been cast by providence without prior consultation. The 'I' of fate has the image of an object" (FD p. 2). Destiny, in the other hand, is outlined as "an active mode of existence, one wherein man confronts the environment into which he was thrown, possessed of an understanding of his uniqueness $[\ldots]$ and of his ability to struggle with his external circumstances without forfeiting either his independence or his selfhood" (ibid). These individual stratums of existence are equally applicable to the national sphere: a nation can subsist as a 'Covenant of Fate' or as a 'Covenant of Destiny'. A fateful nation exists out of necessity and compulsion but this, Soloveitchik insists, is not necessarily pejorative. There are completely positive outcomes from a fateful existence. For example, the nation is granted a distinctive selfunderstanding that subsequently provides her with a rigorous conception of self-identity. National Fate usually comes to being by an externally dictated state of affairs; most commonly a historical experience of suffering that results in the birth of a unified and cooperative nation. For Soloveitchik, the enslavement in Egypt exemplifies the paradigm of fateful existence as a painful yet decisive moment in Jewish history. Alternately, a nation of destiny exists in an aware and resolute way in which it is invested in productive conduct that promotes and deepens its shared spiritual mission. The biblical paradigm for this is the Covenant on Mt. Sinai, where the designation of a Jew's life toward the collective destiny through an undertaking of a specific lifestyle was established. ${ }^{17}$ As mentioned above, fate and destiny as terms pertaining to the volk and its spiritual stance were commonplace amongst volkish thinkers.

As we have seen, the importance of the notion of 'tradition' and its conceptual equivalents in volkish thought cannot be stressed enough. Through tradition the essence of the volk is transmitted from one 
generation to the next and only by the success of the transmission can the volk hope to realize its destiny. Tradition encapsulates the trans-historicality of the volk and points it towards its historical destiny. Unsurprisingly, similar traits are to be found too in Soloveitchik's description of the covenant between God and the Jewish people and halachic way of life, the bedrock upon which the Jewish peoplehood continuity and essence is based on. In LMF, the lonely man of faith - who is ontologically lonely - seeks for a 'we' to redeem him from his existential condition. He therefore establishes a community of covenant whose members are existentially and religiously bound to each other. Although the present members of the community play a substantial role in his existential redemption, the boundaries of the community are nevertheless not confined to the present generation alone. The penetration of the eternal into the mundane everyday which occurs in the moment of covenant 'liberates' the members of the community from being fettered to the present and enables them to experience eternity within time, that is, to experience the convergence of the past, present and future in the moment of now. This is expressed through a spiritual engagement with the generations of the past and the future, thus resulting in the creation of a trans-historical dialogue with a timeless destiny-devoted community. This is how Soloveitchik describes the covenantal moment and its communal ramifications:

"In the covenantal time experience community man of faith finds deliverance from his isolation in the "now" for the latter contains both the "before" and the "after". Every covenantal time experience is both retrospective, reconstructing and reliving the bygone, as well as the perspective, anticipation the "about to be" [...] in prospect, he beholds the full eschatological realization of this covenant, its promise, hope and vision" (LMF p. 42) ${ }^{18}$

The covenantal community in reality is a trans-historical unity of past, present and future generations, gravitating around tradition and flourishing by it. What volkish thinkers often call heritage Soloveitchik refers to as the 'promise, hope and vision' that are encased in the covenantal act and, with respect to the Jewish peoplehood, are manifested through the abidance to the word of God. The transmitted code of conduct that is essential to it and that was passed down from past generations to futurity exhibits the essence 
of the Jewish destiny according to Soloveitchik and it is this that plays a critical role in what unites the Jewish people throughout history.

D.

We have seen then that Solovetichik is influenced by volkish ideas and that he employs them unabashedly into a Jewish context. Yet the dialectic nature of his thought withholds him from presenting a coarse dichotomy between a good mode of sociality (Gemeinschaft) and a bad one (Gesellschaft). For him, a full and profound religious life is constituted by the dialectic dynamic created by both communal experiences. By this Soloveitchik abstains from advocating a world view that defines society as a constant struggle between a community that pushes to fulfill the destiny of the volk and a community that strives for mediocrity, utility and alienation. Although he undoubtedly prefers the community of covenant, which, as we have seen, unfolds the volk's destiny, the halakha, he is nonetheless unwilling to render the natural community as void of religious import. Thus, the volkish terminology adopted by Soloveitchik provides him with a conceptual framework through which he can address the secular members (natural community) of the Jewish people - ambiguous yet far from dismissive. While the degree of philosophical and religious content resulting from his account is in the very least questionable, ${ }^{19}$ it does in any case sprout from a volkish conceptual framework and simultaneously diverges from it. This framework provides Soloveitchik with a language to describe both his discontent from the present religious stature of the Jewish people and his conviction that the modern values and way of life certainly bear religious significance. Traditional and secular communities do, after all, constitute together the united and metaphysical entity of Knesset Israel. Furthermore, portraying the Jewish people as a metaphysical and united entity enriches the theological language as well as adds a sense of unity, partnership and shared responsibility to the nation as a whole. Similarly, depicting the halakha as the Jewish destiny contributes to the relevance of halakha for the contemporary world. Instead of perceiving it as an irrelevant hardship on modern life, Soloveitchik - thanks to volkish terminology - presents it as the fulfillment of the Jewish volk's destiny. Not a burden, it is rather 
the manifestation of the volk's spiritual mission. Volkish language thus supplies Soloveitchik as Jewish thinker with a language that could be religiously - and not only nationally - enriching.

Indeed, perceiving the Jewish people as metaphysically unique or underscoring the importance of tradition are prevalent points in the millennia long Jewish tradition. These alone should not, of course, be categorized as volkish influence. Yet it is difficult to argue that one who perceives halakha as the Jewish destiny, portrays Am Israel as a living, autonomous entity or inserts the social distinction between Gemeinschaft and Gesellschaft into Jewish formulations - as Soloveitchik does - is not, in one way or another, influenced by volkish thought. These notions are not inherently interconnected; identifying halakha as the Jewish destiny does not necessitate a depiction of the Jewish community as an independent, living metaphysical entity, nor does the Gemeinschaft/Gesellschaft distinction naturally or directly infer from Jewish sources. It does seem most correct to maintain that Soloveitchik was influenced by volkish thought. This does not mean, of course, that ideas along these lines are virtually absent from Jewish texts that Soloveitchik was doubtless familiar with. Loosely resembling ideas may be found in the writings of the Maharal, or in certain kabbalistic or Hassidic writers. Is this then not a case of influence but merely of translation of ideas rooted in the Jewish tradition into a language that his contemporaries would respect? While obviously difficult to prove without any trace of doubt, the specific usage of various volkish ideas with their fitting volkish terminology in the various ways we have seen and, as we shall see below, within the relevant historical context, urges us to suggest that it is not that Soloveitchik sought to express traditional Jewish ideas and, inclined to translate them into a language more suitable for the modern Jew, chose the seemingly fitting volkish language. Rather, it seems the other way around: these modern European opinions - with their emphasis on community, tradition, action and vocation - appear to be easily translatable to a Jewish language, a translation that enriches the Jewish language and deepens it.

The following may bolster our claim. Examining Rav Soloveitchik's conception of community through the lens of the volkish ideology could offer an interpretive solution to a challenge that arises from his works. A brief review of his different essays leads to the point that Soloveitchik seemingly uses the term 
'community' rather loosely. At times it denotes intense interpersonal relations between individuals, like the covenantal faith community or as described in his article 'Community'. Yet in other places he talks of a community that amounts to the entire people of Israel, sometimes even over its entire history. These two models of community are clearly distinct and different. How could these two seemingly incompatible notions of community be meant to be the same group of people, as Soloveitchik presumably intends them to be? The volkish understanding of community may help to bridge this gap, for it disagrees to work through the dichotomy of small, intimate community verses entire historical people, or more simply, community verses nation. It provides an ideological framework in which a small, intimate community is part of the wider whole and represents and consists of the entire historical volk, past and future generations included. Each member of the large community is essentially connected to each other, as they grow from the same roots and participate in the same mission. Speaking of the large trans-historical volk does not exclude the intimate community or vice-versa, since they actually denote to the same thing. Thus, through the volkish prism the ostensible disparity in Rav Soloveitchik's distinct models of community can find an elucidation: as an organic, metaphysical entity, both the local Jewish community and the Jewish volk in entirety are, in principal, correctly perceived as a 'community'. This suggests that Soloveitchik had the specific volkish version of community in mind when referring to the Jewish people in these different ways. He didn't sense any disparity because, within the volkish framework, there is no disparity. Seeing his general depiction of the Jewish peoplehood as sprouting from scattered ideas located in different Jewish sources, or at least only from them and not from the more programmatic and cohesive volkish ideology seems highly unlikely.

Asking the historical question - when and by what means was Soloveitchik exposed to volkish thought? could contribute to the discussion. The years as a philosophy student in Berlin of the early thirties of the previous century were formative for the young Joseph Dov Soloveitchik. This is when he encountered the thought of Hermann Cohen and existentialism, two schools of thought that stamped a deep and lasting mark on him. I submit that it is in this period the exposure to the 'ideas of 1914', in their renewed advent in the thirties, had occurred. The exposure to these ideas probably occurred through the simple fact that they were 
'in the air' at the time, politically and intellectually. More specifically, at the time Soloveitchik found great interest in the philosophy of Max Scheler, who partook in the zeitgeist of the time and adhered to volkish ideology. Soloveitchik's close friendship with the young Alexander Altmann, his fellow philosophy student in Berlin, implies too familiarity with volkish ideas. While Soloveitchik wrote his dissertation on Cohen, Altmann was writing his on Scheler, and was also deeply occupied with the volkish aspects of Heidegger's recent Sein und Zeit and their applicability to Jewish theology, as demonstrated in his article "What is Jewish Theology?' (1933). There Altmann discusses some volkish elements in Heidegger's fundamental ontology, writing: “most likely the existential moments, adduced by Heidegger, of 'heritage' (Erbe) and 'destiny' (Schicksal) could prove to be decisive for an understanding of Jewish existence[...] it is characteristic of the Jewish people that they are conscious of their heritage, as well as their destiny, believing that they are always being addressed anew by God [...] it is the actuality of the 'Hear O Israel' $"{ }^{20}$ We can thus confidently submit that the time in Berlin was for the young Soloveitchik a moment of exposure to different approaching the world, one of which was the volkish ideology.

E.

After establishing the influence of volkish thought on Rabbi Soloveithcik and considering the historical background of this influence, we shall now turn to deal with his critique of this ideology. In the following we will suggest that Soloveitchik's reaction to the philosophy of Martin Heidegger can be a test case to reveal the problematic aspects Soloveitchik finds in volkish thought. This discussion will lead to a suggestion as to how Soloveitchik could apply volkish ideas to Judaism while simultaneously holding such a harsh critical position towards them.

Amongst the many thinkers of beginning of the twentieth century associated with volkish ideology, Martin Heidegger should stand out both for the exceptional depth of his thought and for his vile and exuberant endorsement of National Socialism (officially from 1933), a party which indeed celebrated the metaphysical destiny of the German volk. That Heidegger adhered to volkish ideology is discernable from his magus 
opus, Sein und Zeit (1927, henceforth SZ), a work that was at the time of its publication -and amongst many present readers as well - recognized as dealing particularly with existential issues. Heidegger's existentialism is far from advocating for idiosyncrasy or a-social individuality. On the contrary; in section II, chapter 74 of Sein und Zeit Heidegger explicitly avers that Dasein (Heidegger's neologism for finite human existence) finds its authenticity, that is, the fullness of its own being, not as a socially and historically isolated entity but rather through the convergence of its Geschick (Fate) with the Schicksal (Destiny) of its Volk and by an immersion in its Gemeinschaft with which it shares a common Erbe (Heritage) (SZ 383387). ${ }^{21}$ Resolute decisions and actions are executed through Weiderholung (Repetition), a revitalization and actualization of past possibilities, passed down by heritage, in current circumstances. ${ }^{22}$ By delineating the a-priori ontological preconditions of Dasein in its average everydayness, Heidegger locates the realm of authenticity in a community with a shared understanding of its past and its future mission: "But if fateful Dasein, as being in the world, exists essentially in being-with-others, its historizing is a co-historizing and is determinative for it as destiny (Geshick)[...] This is how we designate the historizing of the community (Gemeinschaft), of a people (Volk)" [SZ 384]. ${ }^{23}$ By calling the authentic community of Dasein a Gemeinschaft, Heidegger implies that the fallen society of inauthentic Dasein, the realm in which Das Man determines how one should act, is a Gesellschaft - the industrial, utilitarian and superficially organized society. ${ }^{24}$ For Heidegger, whose belief in and support of the German volk persisted also after the publication of Sein und Zeit, the destiny of the German volk is to lead the world spiritually (geistige Führung der Welt) as a nation of poets and thinkers (Dichter und Denker). In his 'Introduction to Metaphysics' (1935) he refers to the German volk as "the most metaphysical of nations" and calls for a hyperbolic reform in universities as a first step in the much needed rehabilitation and re-orientation of the German spirit. ${ }^{25}$

Throughout his writings, Soloveitchik mentions many philosophers by name. Naturally, some are mentioned more often than others. Heidegger, admittedly, is scarcely mentioned, yet every mentioning of him is accompanied by a hidden or overt reproach. ${ }^{26}$ In an important footnote of Halachic Man, Soloveithcik writes: 
"The entire Romantic aspiration to escape from the domain of knowledge, the rebellion against the authority of objective, scientific cognition which has found its expression in the biologistic philosophies of Bergson, Nietzsche, Spengler, Klages and their followers and in the phenomenological, existential and antiscientific school of Heidegger and his coterie, and from the midst of which there arose in various forms the sanctification of vitality and intuition, the veneration of instinct, the desire of power, the glorification of the emotional-affective life and the flowing, surging stream of subjectivity, the lavishing of the extravagant praise on the Faustian type and the Dionysian personality etc., etc. have brought complete chaos and human depravity to the world. And let the events of the present era be proof! The individual who frees himself from the rational principle and who casts off the yoke of objective thought will in the end turn destructive and lay waste the entire created order. Therefore, it is preferable that religion should ally itself with the forces of clear, logical cognition [...] rather than pledge its troth to beclouded, mysterious ideologies that grope in the dark corners of existence, unaided by the shining light of objective knowledge, and believe that they have penetrated to the secret core of the world". ${ }^{27}$

Heidegger is listed here aside other thinkers who, by their abandoning 'scientific, objective cognition', are rendered to be philosophically responsible for the 'events of the present', a coarse hint, which becomes explicit in other passages, to the horrific years of the Nazi reign.

Near the end of Halakhic Man, in a concluding, inclusio-like footnote, Soloveitchik returns to the topic at hand and continues his previous castigation, this time directed against thinkers who advocated a distorted form of creativity and self-creation. Here he specifically singles Heidegger out:

"This concept of the obligatory nature of the creative gesture, of self-creation as an ethical norm, an exalted value, which Judaism introduced into the world, reverberates with particular strength in the world views of Kierkegaard, Ibsen, Scheler, and Heidegger. In particular, the latter two set the idea of creation at the very center of their philosophies [...] [The] development from 'inauthentic 
existence' to 'authentic existence' in the philosophy of Heidegger (as expressed in Being and Time) symbolize[s] that norm which aspires to the complete realization of man in the ongoing course of his ontic transformations. However, the fate of Maimonides's idea of creation was similar to the fate of Ibn Gabirol's doctrine of the will, as it passed, via Duns Scotus, to Schopenhauer and Nietzsche. Both these ideas, which were pure and holy at their inception, were profaned and corrupted in modern culture [...] the longing for creation was perverted into the desire for brutal and murderous domination. Such views have brought chaos and disaster to our world, which is drowning in blood". ${ }^{28}$

This passage portrays Heidegger as the representative of the distortion of the 'pure and holy' idea of creativity originally incepted in the Jewish world, corrupting it to a point where it became the philosophical grounds for genocide and murder. In another mentioning of the German thinker, Soloveitchik notes:

"It is no mere coincidence that the most celebrated philosophers of the third Reich were outstanding disciples of Husserl. Husserl's intuitionism (Wesensschau), which Husserl, a trained mathematician, strived to keep on the level of mathematical intuition, was transposed into emotional approach to reality. When reason surrenders its supremacy to dark, equivocal emotions, no dam is able to stem the rising tide of the effective stream", ${ }^{29}$

By mentioning Husserl's 'outstanding disciple', Soloveitchik is clearly hinting to Heidegger, who was once Husserl's close student and colleague. One could similarly assume that the 'rising tide' referred to here is again the National Socialistic regime and the intellectual atmosphere that enabled its rise.

Soloveitchik's critique quoted above does not explicitly target volkish thought as such. Yet a deeper glance may provide reasons to tie this critique with what he would have found to be deeply disturbing in this tradition. Thus, it is a notable fact that many of the thinkers stated as intellectually responsible for the horrors of the times were, in fact, volkish thinkers. Nietzsche was famously recruited to the volkish centered Nazi ideology and was held by them as their preeminent harbinger. Klages, Spengler, Heidegger and 
Scheler all produced ideas affiliated with volkish ideology as well. In order to correctly understand the problems Soloveitchik identifies with movements which adhere to "dark, equivocal emotions" - and his reaction to Heidegger is a touchstone for this - a related point is to be made. According to his interpretation of Maimonides' reading of Adam and Eve's sin, the preference of emotion and esthetics over reason is the germ of the 'original sin'. ${ }^{30}$ The modern philosophical tradition that adheres to intuition, emotion, esthetics and power as supreme and absolute principles is the embodiment of the primordial serpent who caused the destruction of the world of Eden and is evidently the source of all evil. As a matter of fact this philosophical tradition has accelerated a second, devastating destruction of 'the entire created order' by the hands of the Nazis. In contrast to this, granting centrality to reason - and not to emotions or intuitions - as the basis of a truth pursuing and ethical life is the sine qua non of Soloveitchik's world view. ${ }^{31}$ I say 'ethical' because Soloveitchik here participates in a rich philosophical tradition beginning in the ancient world, continuing to Maimonides and culminating with Kant and Cohen that postulates the essential interconnectedness of the ethical with the rational. Reason is the ground of ethics, and diminishing the fundamental stature of the former jeopardizes, by definition, the stability of the latter. And although Soloveitchik does not say this explicitly, what is implied by the fact that reason dictates ethics is that ethics must be rationally and objectively justifiable. Thus, the problem with Heidegger's authentic existence or the "emotional approach to reality" rests for Soloveitchik in that actions determined by them are not open to objective scrutiny and do not have the ability to be universally justified. One could do this and another could do the opposite and both are equally legitimate since they lack an overarching objective and decisive principle of ethical evaluation. Anything goes as long as it derives from one's emotions or inner sense of authenticity. In this view, the primary form of justification is not ethical or rational but personal. Ethical boundaries are powerless when the ultimate arbiter is one's personal experience of one's self.

This way of thinking could easily be applied as representing a volkish attitude towards ethics. It is therefore not at all surprising then that most of the thinkers who are mentioned by Soloveitchik as philosophically responsible for the horrors of the times are volkish thinkers. In Soloveitchik's opinion, the bloody history 
of the twentieth century is the ramification of volkish ideology which submits action to private, un-objective principles that serve the volk's triumphalism and supremacism alone. The atrocities in Europe are evidently explained by prevalent annulment of the required subordination to reason-dictated ethics that apply equally to one volk as to the next. Lacking a higher, universal principle that guides one's actions in Heidegger's thought exhibits the problematic aspect characteristic to volkish thought, and it against this position that Soloveitvhik's critique targets. ${ }^{32}$

In this regard it is indeed striking that Soloveitchik articulates salient volkish ideas and concepts. How could he apply ideas from an ideology with which he has fundamental ethical botherations? This apparent disparity between his incorporation of volkish moments on the one hand and the place this ideology inhabited in the thought of the thinkers he so fervently criticized on the other hand can be explained as resting precisely on the answer to the question "are rationality and ethics the measure of action and belief or not?" Since for Heidegger what evaluates actions is, in Soloveitchik mind, a capricious and intuitive whim, it is hardly surprising that he is a philosopher who has declared the Führer as the destiny of Germany. For Soloveitchik, the destiny of the Jewish volk, au contraire, is not arbitrarily determined. In the Jewish case, conduct is not subject to a capricious and irrational determination, since it answers to the word of God as portrayed in halakha. Furthermore, the halakha demands religious actions from Jews; it does not permit them to get away with deeds that were otherwise dubious. It is a challenge, not an excuse. As such it can be the foundation of Jewish life and enable the actualization of the Jewish destiny.

Thus, Soloveitchik employs volkish terms that he finds to be appropriately usable in a Jewish context, yet not without restrictions: the 'repetition' of past conduct is not to be undertaken without the clear orientation of reason. The inner, metaphysical value of Knesset Israel is not founded upon a precarious innerlichkeit, but on an actual relationship with God. Halakha, the Jewish destiny, cannot contradict either universal reason or ethics, and does not therefore fall into the ethical pit other volks have tragically fallen into. 
Soloveitchik's reaction towards volkish ideology is ambivalent: on the one hand it provides a descriptive language for a historical community embedded in traditions that affords its designation as a people and leads it to the acknowledgment of its trans-historical nature and its spiritual destiny. On the other hand, inasmuch as it divorces the luminous path of reason and strives for glorification based on irrational and unobjective principles, it is philosophically poisonous and ethically perilous. The volkish framework is a rich and constructive framework as long as the religious ideas produce through it do not go against reason and ethics. As an isolated normative framework bound to a capricious value system and allergic to the demand of universal justification, it is a source of destruction. But as we have seen, it is not only Soloveitchik's rationalism that thwarts complete adherence to the volkish world view. Also the dialectical nature of Soloveitchik's thought allows him to adopt volkish notions without incorporating their specific normative resolutions. Thus Gemeinschaft and Gesellschaft are used as descriptive forms of communal existence, however by stressing that both modes of sociality are true elements of the dialectical religious existence, Soloveitchik succeeds in evading what would otherwise easily become a coarse binary conception of 'positive' and 'negative' modes of sociality. And given that the Gesellschaft in this case refers to secular Jews (or the secular Zionism movement), what emerges is that the other reason of Soloveitchik's rejection of volkish ethics is his unwillingness to neutralize the import of secular Jews.

Soloveitchik's ambivalent reaction to volkish thought thus exemplifies the promises and perils of an appropriation of this ideology into a Jewish context.

\footnotetext{
Notes:

${ }^{1}$ See: Mosse, George L. "Influence of the Volkish Idea on German Jewry' in: Germans \& Jews: The Right, the Left, and the Search for a 'Third Force' in Pre-Nazi Germany”, (New York 1970).

${ }^{2}$ See: Sokol, Moshe. "Transcending Time: Elements of Romanticism in the Thought of Rabbi Joseph B.

Soloveitchik", Modern Judaism, 30, 3 (2010), pp. 233-246. Volkish thought shares some fundamental presumptions with romanticism, yet it is a distinct body of ideas and as such deserves separate examination.
} 
${ }^{3}$ A comprehensive history of the term 'volk' involves abounding references to a handful of nationalist thinkers and movements and obviously lies beyond the purview of the present essay. The main focus of the abridged presentation that will be offered here is the volk in its German context, although volkish moments were by no means confined to Germany, and more importantly, only the notions that will contribute to the following discussion on Soloveitchik's relation to volkish thought will be addressed.

${ }^{4}$ See: Berlin, Isaiah. "Nationalism: Past Neglect and Present Power”, in: Against the Current, Henry Hardy ed. (Princeton 2013) p. 431.

${ }^{5}$ Huizinga, Johan. "Patriotism and Nationalism” In: Men and Idea: History, the Middle Ages, the Renaissance, trans, James S. Holmes and Hans van Marle (New York 1959) p. 155.

${ }^{6}$ The terms 'fate' and 'destiny' were employed at the time by both volkish and non-volkish thinkers, who instilled into them different meanings in accordance with each thinkers polemical needs. For example, for Georg Simmel (1858-1918), who used 'fate and 'destiny' in his article 'Das Problem des Schicksal' (1913), Shicksal connoted the transience of the contingent and arbitrary to a meaningful and purpose-laden end. In contrast, Oswald Spengler (1880-1936) employed Shicksal in his 'Der Untergang des Abendlandes' (1918), alluding to a pessimistic world view of a tragic pre-determined history. Martin Buber used 'fate' and 'destiny' in his lecture on Jewish nationalism given in Carlsbad as part of the Zionist congress in 1921 and published in 1936 as 'Zion als Zeil und Aufgabe'. See footnote 16 below.

7 Fichte, Johann Gottlieb. Addresses to the German Nation, trans. R. F. Jones \& G. H. Turnbull (Chicago, 1922), p. 137.

${ }^{8}$ Young, J. Heidegger, Philosophy, Nazism, (UK 1997) p. 14.

${ }^{9}$ Horwitz, Rivka. "Yaḥaso Shel Harav Soloveitchik Laḥvaya Hadatit Velemistorin”, in: Emuna Bizmanim Mishtanim, (Jerusalem 1997) p. 50 [The translation from Hebrew is mine, D.H].

${ }^{10}$ Ish-Shalom, Binyamin. "Hasafa Kekategoriya Datit Behaguto Shel J.D Soloveitchik", in: Jubilee Book in Honor of Rav Mordechai Breuer, ed. M. Bar-Asher (Jerusalem 1992) pp. 799-821 [The translation from Hebrew is mine, D.H].

${ }^{11}$ Soloveitchik, Joseph B. “Community” in: Tradition, 17, 2 spring (1978), p. 3.

${ }^{12}$ Peli, Pinchas H. On Repentance: The Thought and Oral Discourses of Rabbi Joseph Dov Soloveitchik, (Maryland 2004) p. 120. 
${ }^{13}$ Soloveitchik, Joseph B. The Lonely Man of Faith, (New York 1992).

${ }^{14}$ Fishman, A. "Ish Haemuna Haboded Beprespektiva Soẓiologit” in: Emuna Bizmanim Mishtanim (1997) pp. 265274.

${ }^{15}$ Soloveitchik, LMF pp. 40-42.

${ }^{16}$ Soloveitchik, Joseph B. Fate and Destiny: From the Holocaust to the State of Israel, (New York, 2000) pp. 58-59.

${ }^{17}$ According to Blidstein, the source of the terms 'fate' and 'destiny' in Soloveitchik, as well as their juxtaposition to Exodus and Mt. Sinai, is Martin Buber's lecture on nationalism given at the Zionist congress in Carlsbad, 1921. See: Blidstein, Gerald J. "Fate" and "Destiny", in: Society and Self, (New York 2012); Berger, M. "U-Vikashtem Misham: Rabbi Joseph B. Soloveitchik's Response to Martin Buber's Religious Existentialism”, in: Modern Judaism vol. 18, 2 (1998). Taking into account the general volkish background of these terms, an attempt to uncover a specific thinker from which Soloveitchik adopted 'fate' and 'destiny' seems highly improbable. That said, it could be determined with a fair amount of confidence that Soloveitchik, who no doubt read Buber and was deeply influenced by him, did not receive these concepts from Buber, whose aforementioned lecture was only published in 1936. A more plausible suggestion, although indeed a surmise as well, would be that Soloveitchik first encountered these terms as philosophical and existential notions in Heidegger's Sein und Zeit, which was published in 1927. As we shall later see, Soloveitchik was familiar with this work. In any case, there is little reason to tie Soloveitchik's volkish language and ideas to his proven familiarity with Buber's work. Rather, both thinkers adopted notions from this strain of thought and applied them, albeit differently, to the Jewish case.

${ }^{18}$ The description of the covenantal moment indicated here is a Jewish and communal adaptation of Kierkegaard's notion of Oieblik, a 'Blink-of-an-Eye', or 'the Decisive Moment', as it is occasionally rendered in English. For a more elaborate analysis of Soloveitchik's employment of this Kierkegaardian notion, see my: "Authenticity, Repentance and the Second Coming: 'the Moment' in Kierkegaard, Heidegger and Rabbi Soloveitchik", in: Journal of Scriptural Reasoning (accepted).

${ }^{19}$ Much has been written on the topic. For an analysis and critique of Soloveitchik's view of secularity, see: Blidstein, Gerald J. "A Religious-Zionist Thinker?" in: Society and Self, 2012; Roznak, Michael. "Haadam Hayehudi Vehamedina” in: Sefer Hayovel Lehagaa'on Rabbi Yoseph Dov Soloveitchik (1984) pp. 152-169; Schwartz, Dov. "Erez Hahalakha: Harav Soloveitchik Veḥugo", in: Erets Hamamashut Vehadimyon: Ma'amada shel Erez Yisrael Bahagut Haẓionit Hadatit, (Tel Aviv 1997). 
${ }^{20}$ Altmann, Alexander. "What is Jewish Theology?", in: The Meaning of Jewish Existence, Theological Essays 1930-1939, ed. Alferd L. Ivry, (NH 1991) pp. 54-55.

${ }^{21}$ Vogel offers an existentialistic, communitarian and cosmopolitan reading of SZ. The first generally represents Sartre's interpretation of the book and the third is a contemporary attempt to read current ideas into it. The second is probably how Heidegger intended his work to be understood and it is the only way to correctly interpret concepts such as: Dasein, Mit-Sein, Heritage, Fate, Destiny and Volk. This reading also takes into account the historical and cultural background of the time the book was written. See: Vogel, Lawrence. "The Fragile "We": Ethical Implications of Heidegger's Being and Time" (Illinois 1994); Fritsche, Johannes. Historical Destiny and National Socialism in Heidegger's Being and Time, (Berkley 1999). See also: Phillip, James. Heidegger's Volk: Between National Socialism and Poetry, (California 2005) pp. 95-132.

${ }^{22}$ Guignon calls it "transmitters of tradition". See: Guignon, Charles. "History and Commitment in the Early Heidegger", in: Heidegger: A Critical Reader, eds. H. L. Dryfus and H. Hall, (Oxford 1992) pp. 130-142.

${ }^{23}$ Heidegger, Martin. Being and Time, translated by J. Macquarrie and E. Robinson, (New York 2008). Many define these passages as the preemptive hints to his future enthusiasm for Nazism.

${ }^{24}$ Sluga finds Fichtenian traces in Heidegger's political thought, and both Young and Fritsche, complementing Sluga, recognize 'ideas of 1914' in his political thought. See: Young, 1997; Sluga, Hans. Heidegger's Crisis: Philosophy and Politics in Nazi Germany, (Cambridge, USA 1993) pp. 101-124; Fritsche, 1999.

${ }^{25}$ Heidegger, Martin. Introduction to Metaphysics, trans. by R. Manheim, (New York 1961) p. 38; Heidegger, Martin. "The Self-Assertion of the German University”, in: Martin Heidegger and National Socialism, Gunther Neske \& Emil Kettering (eds) (New York 1990) pp. 5-13.

${ }^{26}$ Taking this fact into consideration, we must first determine to what extent was Soloveitichk familiar with Heidegger's philosophy. According to Schwarz, the answer to this is unclear. Schwarz suggests that Soloveitchik learnt of Heidegger through Buber's critical discussion of him in the latter's 'Eclipse of God', or through Hugo Bergmann's book 'Hogey Hador', to which Soloveitchik alludes to in 'Halakhic Man' when discussing Heidegger. See; Schwarz, Dov. 'Haguto Hafilosophit shel harav Solovetichik: Ish Hahalakha, Dat O' Halakha?' (Alon Shvut 2004) p. 30, 356. However, there is ample evidence that Soloveitchik had a deeper familiarity with Heidegger's thought than suggested by Schwarz. As a philosophy student in Berlin of the early 30's, immediately after the publication of SZ, it is very likely that he read the freshly renowned work. Hanna Arendt, in her words given for the 
celebration of Heidegger's eightieth birthday, proclaimed that amongst philosophy students in Germany in the time prior to the publication of Sein und Zeit circled 'rumors of a hidden king' regarding Heidegger. See: Arendt, Hanna. "Heidegger at Eighty", translated from German: Albert Hofstadter, The New York Review of Books October 21, 1971. Furthermore, in his introduction to the composition of Alexander Altmann's early theological writings, Paul Mendes-Flohr reports a pertinent historical testimony disclosed to him by Altmann himself: “in his [Altmann's] philosophy classes he befriended a fellow student, Joseph Dov Soloveitchik [...] the affinity between these two men was immediate; both were deeply grounded in traditional Judaism and both had insatiable interest in philosophy. Attending many of the same courses for two, perhaps three years, Altmann and Soloveitchik would meet virtually every day, often taking long, peripatetic walks in Berlin's rambling Tiergarten and engaging in passionate discussion about philosophy and Judaism". See: Mendes-Flohr, Paul. "Theologian Before the Abyss", 1991, p. xviii. As philosophical interlocutors at the time in which Altmann was seriously engaged with Heidegger's thought and its possible implementation to Jewish theology, Soloveitchik, in all probability, participated in this philosophical endeavor and too engaged with Heidegger. As a matter of fact, Aaron Rakeffet-Rothkoff, Soloveitchik biographer, states that in a convention held in 1968 Soloveitchik admitted to have taken a seminar under Heidegger in Berlin: "I was in Heidegger's class. I was a good student. He continually spoke about human destiny, spiritual perceptions, and the events of that time." See: Rakeffet-Rothkoff, Aaron. The Rav: The World of Rabbi Joseph B. Soloveitchik, vol. 1 (New York 1999) p. 195. Unfortunately, this fascinating and opaque testimony lacks any further information that might shed light on the presumed event. It is additionally difficult to determine when Heidegger - who had twice declined an offer from University of Berlin to take up a post there - gave there a seminar so that Soloveitchik's attendance would be possible, and what was the topic of discussion. A relative of Soloveitchik who I have approached concerning this issue - a Soloveitchik scholar himself - has had no further information about it. It is possible that the reference here is to a single lecture and not a full academic seminar. In any event, this testimony assures Soloveitchik's acquaintance of Heidegger as more than just that of second-hand reading.

${ }^{27}$ Soloveitchik, Joseph B. Halakhic Man, p. 141, footnote 4.

${ }^{28}$ Ibid. p. 164, footnote 147.

${ }^{29}$ Soloveitchik, Joseph B. The Halakhic Mind, (New York 1986) p. 53. 
${ }^{30}$ See: Harvi, Zeev. "Hearot al Harav Soloveitchik vehafilosofiya Harambamit", in: Emuna Bizmanim Mishtanim, pp. 100-101.

${ }^{31}$ In later works, Soloveitchik expresses opinions that demonstrate a diminishing stature to reason. It is curious to wonder what would be his arguments against these thinkers when reason and ethics no longer hold their supreme position and are thus no longer the essential difference between legitimate appropriation of volkish notions and ethically perilous volkish supremacism.

${ }^{32}$ It should be noticed that Soloveitchik diatribe of Heidegger is not strictly ad hominem. His argument begins ad rem and concludes within proximity of an ad hominem attack, thus pointing to the fact that Heidegger's endorsement of Nazism was made on his own philosophical terms. A more thorough and philosophically informed critique of Heidegger bearing the same ad rem to ad hominem dynamic was presented by Buber in his inaugural lectures at the Hebrew University which were published under the title "What is a Man?" in: Buber, Martin. Between Man and Man, Boston, 1955. And see David Novak's analysis of this critique in his "Buber's Critique of Heidegger" in: Modern Judaism, Vol. 5 No. 2 May (1985), pp. 125-140. Heidegger himself admitted to the connection between his philosophy and his political endeavors. On this, see: Löwith, Karl. "My Last Meeting with Heidegger in Rome", in: Heidegger's Controversy: A Critical Reader, ed. Richard Wolin (USA 1993). 